\title{
РОЛЬ ВИКЛАДАЧА-КУРАТОРА У ВИХОВНІЙ РОБОТІ ЗІ СТУДЕНТАМИ
}

\author{
К. Л. Чурпій
}

Кіровоградський інститут розвитку людини

\section{THE ROLE OF TEACHER-SUPERVISOR IN EDUCATIONAL WORK WITH STUDENTS}

\author{
K. L. Churpiy \\ Kirovohrad Institute of Human Development
}

\begin{abstract}
Робота викладача-куратора будується на чотирьох основних напрямках виховної роботи. Всі вони пов'язані між собою, доповнюють один одного, спрямовані на виховання і формування не лише висококваліфікованого спеціаліста, але й громадянина високої духовності і моралі, патріота своєї країни.
\end{abstract}

Work of a teacher-supervisor is built on four basic directions of educational work. All of them are constrained, complement each other, aimed at education and forming not only of a highly skilled specialist but a citizen of high spirituality and moral, patriot of the country.

Вступ. Головним завданням, що стоїть перед викладачами вищих навчальних закладів на сучасному етапі, крім підготовки фахівця відповідної галузі, який відповідає потребам сьогодення, $є$ формування особистості студента. Період навчання у ВНЗ передбачає створення фахівця - всебічно і гармонійно розвиненої особи, майбутнього патріота і громадянина - носія високої моралі та духовності [1]. Такий напрям навчально-виховного процесу базується на принципі гуманізації навчального закладу, який грунтується на утвердженні людини як вищої соціальної цінності, про що записано в Конституції України, створення умов для розвитку здібностей людини [2]. Наступний напрям - це гуманітаризація освіти, яка передбачає формування молодої людини, виховання у неї відповідального ставлення до навколишнього середовища.

Мета роботи - дати теоретичне обгрунтування значення ролі викладача-куратора у виховній роботі зі студентами.

Основна частина. Куратор групи студентів у ВНЗ - це викладач з відповідним досвідом виховної роботи, життєвим досвідом, вихователь 3 широким кругозором і властивостями лідера. В кожному випадку викладач - куратор, визначивши конкретну проблему, вибирає комплексний підхід для її вирішення, куди включаються індивідуальні бесіди на відповідні теми, екскурсії, зустрічі з цікавими людьми, відвідування ๑) К. Л. Чурпій історичних міст або інші форми і методи роботи [3]. Робота куратора групи будується індивідуально в кожному випадку: це колективна робота з усією групою або робота індивідуально з кожним ії членом. Тобто робота викладача-куратора з групою має комплексний підхід для вирішення конкретно поставлених задач, використовуючи різні форми виховання i досягнення мети. Робота для досягнення цілі проводиться шляхом проведення бесід, екскурсій, наведення прикладів 3 життя видатних людей, прикладів 3 життя конкретних членів групи. Роль куратора групи на даному етапі виховної роботи - це роль організатора, натхненника студентської творчості, генератора ідей по розвитку загальноосвітніх знань, духовного розвитку студентів.

Виховна робота куратора групи може бути розбита на кілька блоків, які мають втілюватися одночасно і не мають бути відірвані один від одного. Кожен блок якоюсь мірою може дублювати інший, разом 3 тим доповнюючи його.

1. Найбільш важливим питанням у вихованні студентів є робота по вихованню патріотизму, яка включає суспільно корисну орієнтацію студентів, виховання гідності у них, створення чітких, цільних, орієнтирів національної самовідданості студентів, залученню до вивчення і примноження багатих традицій національної інтелігенції, розвитку української нації, іiі історичної свідомості, традицій, української 
науки і культури. Робота по вихованню патріотизму передбачає виховання гідності у людини, глибоке усвідомлення необхідності захисту суверинітету i територіальної цілісності держави. Для кожного студента повинні стати невід'ємними потреба і можливість відчути себе як особистості в суспільстві, нації, країні. Без виховання у людини любові до своєї держави, до свого народу неможливо виховати високоінтелігентну людину, а значить і висококваліфікованого фахівця.

2. У навчально-виховній роботі куратор групи виступає як викладач 3 передачею студентам любові до навчання, важливості отримання належної освіти, передачі любові до предмета викладання. Коли людина не переконана в чомусь сама, переконати інших в даному напрямку марна справа. Перш за все, викладач повинен особистим прикладом на всіх етапах своєї роботи у спілкуванні $з$ колегами, студентами демонструвати основні високі етичні та моральні норми поведінки, чуйного ставлення, поміркованих реакцій на ті чи інші події. Куратор повинен бути творчим викладачем, багатогранним і всебічно освіченим. Дуже велику роль у навчальній діяльності куратора і викладанні, виховному процесі відіграють глибоке знання предмета, застосування різних методик викладання, розуміння психофізіологічних особливостей студентів, знання їх проблем і умов життя, коло їх знайомств і інтересів.

3. Психолого-педагогічна робота планується куратором, виходячи з аналізу їі результатів. Проводячи виховну роботу серед студентів, він виступає в різних ролях і іпостасях. В одному випадку він буде виступати як співрозмовник, однодумець у справі, колега. 3 іншого боку, як педагог 3 життєвим досвідом, практик, який працює на основі знання теорії виховання, аналітик нестандартних ситуацій. У процесі виховання куратор вирішує завдання по здійсненні зв’ язку теорії і практики, вміння планувати виховні заходи в групі для всіх і для кожного індивідуально, навчання роботи в бібліотеці, поєднання теоретичної частини навчання 3 практичною. Велике значення для студента має відвідування музеїв, театрів, вивчення історії краю. Важливим є спільна робота куратора i студентів по зміцненню відносин у колективі між ку-

\section{Література}

1. Дроб'язко П. Українська національна школа: витоки і сучасність / П. Дроб'язко. -К. : Академія, 1997. - 181 с.

2. Конституція України // Відомості Верховної ради Ук- ратором і студентами, розуміння один одного, що дає належні результати по вихованню. В особі куратора студенти мають бачити, крім керівника групи, порадника і свого захисника.

4. Науково-методична робота будується на основі постійного педагогічного та наукового пошуку. До цієї роботи куратору слід залучати найбільш обдарованих студентів, талановитих активних дітей. Робота має бути побудована шляхом участі студентів у роботі наукових гуртків, підготовки наукових виступів на студентських конференціях не лише в навчальному закладі, але і в інших навчальних закладах України. Робота в наукових гуртках у студентів розвиває аналітичне мислення, сприяє поглибленому вивченню та ознайомленню 3 проблемними питаннями відповідної галузі або предмета і шляхи їх вирішення. У студентів формується потреба наукового пошуку, що важливо після закінчення навчання і використання набутих знань у практичній роботі. Робота в наукових гуртках одних студентів стимулює і розвиває інтерес до науки в інших. І роль куратора групи тут надзвичайно велика і відповідальна. Однак не повинно бути у куратора поділу серед студентів на талановитих і “середняків". Розвиток інтересу до наукової роботи серед студентів і наукового пошуку - одне із важливих завдань куратора групи.

Всі студенти - це майбутні інтелігенти країни, які займають особливе положення в суспільстві і мають відповідні права і обов' язки. Тому у роботі з студентами обов'язковим виховним моментом має бути формування національної свідомості, гордості за рідну країну. Наполегливе навчання та самовіддана праця, прищеплення любові до рідного краю і його народу, шанування традицій і виховання патріотизму є основою у формуванні громадянина України.

Висновок. Робота куратора-викладача будується на чотирьох основних напрямках виховної роботи. Всі вони пов'язані між собою, доповнюють один одного, спрямовані на виховання і формування не лише висококваліфікованого спеціаліста, але й громадянина високої духовності і моралі, патріота своєї країни. Така виховна робота направлена на формування прошарку інтелігенції з високою національною свідомістю і відповідальністю за свою державу.

раїни. - 1996. - № 30. - Ст. 141.

3. Соколов В. М. Стандарти в керуванні якістю освіти / В. М. Соколов. -К. : Вища освіта в Україні, 2000. - 77 с. 